\title{
Estrogen receptor a-coupled Bmi1 regulation pathway in breast cancer and its clinical implications
}

Huali Wang ${ }^{1+}$, Haijing Liu' ${ }^{1+}$, Xin $\mathrm{Li}^{1}$, Jing Zhao ${ }^{1}$, Hong Zhang ${ }^{1}$, Jingzhuo Mao ${ }^{1}$, Yongxin Zou', Hong Zhang ${ }^{1}$, Shuang Zhang' ${ }^{2}$, Wei Hou', Lin Hou', Michael A McNutt ${ }^{1}$ and Bo Zhang ${ }^{\text {** }}$

\begin{abstract}
Background: Bmi1 has been identified as an important regulator in breast cancer, but its relationship with other signaling molecules such as ERa and HER2 is undetermined.

Methods: The expression of Bmi1 and its correlation with ERa, PR, Ki-67, HER2, p16 ${ }^{\text {INK4a }}$, cyclin D1 and pRB was evaluated by immunohistochemistry in a collection of 92 cases of breast cancer and statistically analyzed. Stimulation of Bmi1 expression by ERa or 17ß-estradiol (E2) was analyzed in cell lines including MCF-7, MDA-MB-231, ERa-restored MDA-MB-231 and ERa-knockdown MCF-7 cells. Luciferase reporter and chromatin immunoprecipitation assays were also performed.
\end{abstract}

Results: Immunostaining revealed strong correlation of Bmi1 and ERa expression status in breast cancer. Expression of Bmi1 was stimulated by 17ß-estradiol in ERa-positive MCF-7 cells but not in ERa-negative MDA-MB-231 cells, while the expression of Bmi1 did not alter expression of ERa. As expected, stimulation of Bmi1 expression could also be achieved in ERa-restored MDA-MB-231 cells, and at the same time depletion of ERa decreased expression of Bmi1. The proximal promoter region of Bmil was transcriptionally activated with co-transfection of ERa in luciferase assays, and the interaction of the Bmi1 promoter with ERa was confirmed by chromatin immunoprecipitation. Moreover, in breast cancer tissues activation of the ERa-coupled Bmi1 pathway generally correlated with high levels of cyclin D1, while loss of its activity resulted in aberrant expression of $\mathrm{p}^{16^{1 \mathrm{NK} 4 \mathrm{a}}}$ and a high Ki-67 index, which implied a more aggressive phenotype of breast cancer.

Conclusions: Expression of Bmi1 is influenced by ERa, and the activity of the ERa-coupled Bmi1 signature impacts p16 $6^{\mathrm{NK} 4 a}$ and cyclin D1 status and thus correlates with the tumor molecular subtype and biologic behavior. This demonstrates the important role which is played by ERa-coupled Bmi1 in human breast cancer.

Keywords: Bmi1, Estrogen receptor a, p16 ${ }^{\text {INK4a }}$, Cyclin D1, Breast cancer

\section{Background}

Breast cancer which is currently the most common malignant tumor in females worldwide, shows characteristic heterogeneity that has a genetic or molecular basis. Thus far at least five molecular subtypes of breast cancer have been defined that include Luminal-A, Luminal-B, Luminal-B-HER2, HER2-enriched and basal

\footnotetext{
* Correspondence: zhangbo@bjmu.edu.cn

${ }^{\dagger}$ Equal contributors

'Department of Pathology, Health Science Center of Peking University, 38 Xueyuan Road, Haidian District, Beijing 100191, China

Full list of author information is available at the end of the article
}

like. Definition of these subtypes has allowed treatment to be tailored directly for each type in breast cancer, and marked progress has been made in improving patient survival rate [1]. However, varying sensitivity to treatment and resistance to endocrine or targeted therapy which may be found de novo or may be acquired still presents a therapeutic challenge. Much effort is still needed to completely characterize all the molecular details which may be related to therapeutic targets in breast cancer.

As a hormonally driven tumor, breast cancer is closely associated with estrogen and its $\alpha$ receptor $(E R \alpha)$, in

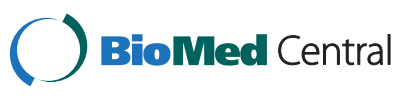


either the process of carcinogenesis or in tumor biology. Up to $70 \%$ of breast cancers show ER $\alpha$ expression, and two-thirds of ER $\alpha$-positive breast carcinoma patients respond to treatment with anti-estrogen therapy [2-4], while breast cancer lacking ER $\alpha$ expression does not benefit from endocrine treatment. Nevertheless, many patients with ER $\alpha$ positive cancer are unresponsive to endocrine therapy, and all patients with advanced disease eventually develop resistance to the therapy $[2,5]$. $E R \alpha$-associated signaling has therefore become a topic of significant interest in the battle against breast cancer. Like other steroid receptors, ER $\alpha$ can directly activate its target genes such as PR and cyclin D1 through an interactive element (ERE, estrogen responsive element) [6]. In a recent study, ER $\alpha$ has been shown to cross talk with other growth factor pathways (non-genomic activity) [6]. In addition to genetic and protein interaction, epigenetic mechanisms of ER $\alpha$ regulation have also received attention in recent years. Silencing or reactivation of ER $\alpha$ by epigenetic regulation has been demonstrated in cultured breast cancer cells [7]. At the same time, the expression of HOXB13 or CDK10 regulated by promoter methylation affects ER $\alpha$ status [8,9]. Moreover, epigenetic modification has been documented in breast cancer.

Bmi1 (Bmil polycomb ring finger oncogene) which encodes a polycomb ring finger protein, was originally cloned as a $c-m y c$ cooperating oncogene in murine lymphoma [10]. It has subsequently been identified as a transcriptional repressor belonging to the polycomb group (PcG) proteins, and is also a key factor in the polycomb repressor complex 1 (PRC1), which serves as an important epigenetic regulatory complex for modulation of chromatin remodeling [11]. To date, many PRC1 target genes have been identified including homeobox (HOX) genes and $p 16^{I N K 4 a}$, whose promoters contain interactive elements which bind directly to Bmi1 [12]. A striking finding in recent studies is that the activity of Bmi1 is indispensable for cell survival and self-renewal of stem cells or cancer stem cells [13-15]. Over-expression of Bmi1 has been found in a large number of human cancers, and a set of 11 genes which make up the Bmil signature has been defined in colorectal, breast, lung and prostate cancers [16-18]. Bmi1 expression in breast cancer has also been found to be associated with other tumor genes [19-21] and in vitro models have demonstrated Bmi1 is required for metastasis of breast cancer [22]. However, there has been no demonstration of any relationship of Bmi1 with other significant factors in breast cancer such as ER $\alpha$, PR, HER2 and Ki-67.

In this study, we at first identified a strong correlation of ER $\alpha$ status with Bmil expression in a collection of breast cancer tissues, and we then demonstrated the positive regulatory role $\mathrm{ER} \alpha$ may play in transcriptional expression of the Bmi1 gene. The ER $\alpha$-coupled Bmil regulatory pathway was subsequently evaluated with regard to its down-stream genes such as $p 16^{I N K 4 a}$ and cyclin $D 1$ and clinicpathological features in breast cancer. Results strongly suggest the ER $\alpha$-coupled Bmil regulatory pathway may be one of the main regulatory mechanisms in breast cancer, whose activity determines the down-stream gene status of $p 16^{I N K 4 a}$ and cyclin D1, and consequently impacts the biologic behavior of breast cancer.

\section{Methods}

\section{Ethics statement}

Paraffin-embedded archival breast cancer tissues were obtained from the Pathology Department of Peking University Third Hospital. This study was conducted after receiving approval from the Peking University Health Science Center Institutional Review Board (IRB). Primary tumor samples were all collected from archival tissues with deletion of all patient identifiers from the retrospective clinical data used in our study. Sample and data collection were approved for informed consent waiver by the IRB.

\section{Tissue specimens}

Tumor samples were obtained from radical mastectomies in 92 cases of invasive breast carcinoma confirmed by histopathology in the Pathology Department of Peking University Third Hospital. All cases were scored histologically as grade I, II and III, according to the Nottingham grading criteria which includes extent of formation of glandular lumina, nuclear atypia and the mitotic index. The TNM classification classes $\mathrm{T} 1$ to $\mathrm{T} 4$ were used to evaluate the tumor size (T1: $\leq 2 \mathrm{~cm}, \mathrm{~T} 2:>2 \mathrm{~cm}$ but $\leq 5 \mathrm{~cm}$, T3: $>5 \mathrm{~cm}$ and T4: tumor of any size, with direct extension to chest wall or skin). The clinical characteristics of the patients are summarized in Additional file 1: Table S1. Tumor tissues were fixed in $4 \%$ neutral-buffered formaldehyde solution ( $\mathrm{pH}$ 7.0) and were routinely processed for paraffin embedding. Sections of $4 \mu \mathrm{m}$ were used for immunohistochemistry staining.

\section{Immunohistochemistry (IHC)}

Paraffin-embedded sections were hydrated with serial treatment with xylene and graded alcohols. Endogenous peroxidase activity was blocked with $0.3 \%$ hydrogen peroxide for $60 \mathrm{~min}$. Antigen retrieval was carried out by heating at $95^{\circ} \mathrm{C}$ in $2 \times 10^{-2} \mathrm{M}$ citrate buffer ( $\mathrm{pH}$ 6.0) or $10^{-3} \mathrm{M}$ EDTA buffer (PH 8.0) for $20 \mathrm{~min}$. After blocking with horse serum $(1: 100)$, sections were incubated with primary antibody (Additional file 1: Table S2) diluted with $\mathrm{PBS}$ to various concentrations at $4^{\circ} \mathrm{C}$ overnight, followed by washing in PBS. Antibody reactions were colorized with the Dako REAL ${ }^{\mathrm{TM}}$ EnVision $^{\mathrm{Tm}}$ Detection System (Dako, Glostrup, Denmark). Sections were counterstained with Mayer's hematoxylin. Positive and negative (primary antibody replaced by PBS) controls were included for all staining procedures. 


\section{Staining evaluation}

Immunohistochemistry (IHC) staining was evaluated independently by two pathologists blinded from the clinical data. Bmi1, cyclin D1 and pRB generally showed nuclear staining in a diffuse pattern, and a negative reaction was defined as absence of staining or occasional positive cells which were less than $5 \%$ of the total tumor cells. ER $\alpha$ and PR were scored as positive if at least 1\% of tumor cell nuclei were positive [23], but in our collection of specimens, a positive reaction typically had more than $20 \%$ positive cells. HER2 was scored by accepted criteria where intensity and completeness of membrane staining were evaluated as previously described [24]. Ki-67 values were calculated as the percent of positively stained cells in at least three randomly selected high power fields ( $\times 40$ objective) [25]. The aberrant expression of p16 ${ }^{\mathrm{INK} 4 \mathrm{a}}(+)$ in cancer cells was defined by cytoplasmic staining with or without nuclear staining, distributed either multifocally (10\%-49\% of cancer cells) or diffusely ( $\geq 50 \%$ cells). Negative staining (-) was defined as no staining in any cells, or no more than only occasional positive cells (less than 5\%). The subtypes in immunohistochemistry were classified according to the reference and the cutoff of $\mathrm{Ki}-67$ for determination of Luminal-A or $-\mathrm{B}$ is $14 \%$ [1].

\section{Statistical analysis}

All data were analyzed with SPSS statistical software (Version 13.0, Chicago, IL, USA). Relationships between tumor markers and other parameters were analyzed using the $\chi^{2}$-test, Pearson Chi-square test, Fisher's exact test or Student's t test. $P$-values of less than 0.05 were considered to be statistically significant and tests were two tailed.

\section{Cell culture and treatment}

Human breast carcinoma MCF-7 and MDA-MB-231 cell lines were maintained in DMEM (GIBCO, Carlsbad, CA, USA) supplemented with 10\% FBS (HyClone, Logan, UT) at $37^{\circ} \mathrm{C}$. For steroid treatment, cells were first cultured in phenol-free DMEM (GIBCO) containing 10\% double charcoal-stripped FBS (Bioind, Kibbutz Beit Haemek, Israel) for $72 \mathrm{~h}$ and then incubated with $10^{-8} \mathrm{M} 17$ $\beta$-estradiol (E2) (Sigma, St Louis, MO, USA) or $10^{-6} \mathrm{M} 4$ Hydroxytamoxifen (4-OHT) (Sigma) dissolved in ethanol, or with ethanol only (as a vehicle control) for indicated lengths of time.

\section{Western blot}

Total protein samples from cell lysates were resolved on SDS-polyacrylamide gels of different concentrations and transferred onto nitrocellulose membranes (Amersham Pharmacia Biotech, Uppsala, Sweden). After blocking with $5 \%$ nonfat milk for $60 \mathrm{~min}$, membranes were incubated with appropriate primary antibodies (Additional file 1: Table S2) at $4^{\circ} \mathrm{C}$ overnight, followed by incubation with alkaline phosphatase-conjugated secondary antibody, and were visualized using NBT/BCIP (Promega, Madison, WI, USA). Densitometry was performed with Image J (1.42q Software, NIH Public Domain).

\section{Plasmids and transfection}

Human Bmi1 [GenBank: NM_005180] was amplified with primers 5'-GCAGATCTATGCATCGAACAACGAG-3' (forward) and 5'-GCGTCGACTCAACCAGAAGAAGT TG-3' (reverse). Total RNA was isolated from cells with Trizol reagent according to the manufacture's protocol (Invitrogen, Carlsbad, CA, USA) and was reversely transcribed into cDNA with AMV reverse transcriptase (Promega). The PCR product was digested with appropriate restriction enzymes and subcloned into multiple cloning sites of the pcDNA3.1/HisC vector (Invitrogen) and sequenced, generating pcD-Bmi1. The pcDNA3.1-ER $\alpha$ expression plasmid was a gift from Dr. Yongfeng Shang.

By using Lipofectamine 2000 reagent (Invitrogen), MCF-7 cells were transiently transfected with pcD-Bmil. MDA-MB-231 cells were transfected with pcDNA3.1-ER $\alpha$ (or empty vector) following the manufacture's instruction and selected in G418 (0.6 mg/ml). The stable clones which were generated were designated as $231 / \mathrm{ER} \alpha$ and $231 / \mathrm{vec}$, respectively.

\section{Gene silencing with small interfering RNAs (siRNAs)}

Three pairs of double-stranded siRNAs were synthesized (GenePharma, Shanghai, China) based on the ER $\alpha$ mRNA sequence [GenBank: NM_000125.3], including siRNA1 sense-5' -CAGGCCAAAUUCAGAUAAUTT-3', and an tisense-5' -AUUAUCUGAAUUUGGCCUGTT-3'; siRN A2: sense-5' -GAGGGAGAAUGUUGAAACATT-3', and antisense-5'-UGUUUCAACAUUCUCCCUCTT-3'; and si RNA3 sense -5'-GGUCCACCUUCUAGAAUGUTT-3', and antisense-5'-ACAUUCUAGAAGGUGGACCTT-3'. $4 \times 10^{5}$ cells in 6 -well plates were transiently transfected with 100 pmol ER $\alpha$ siRNA using Lipofectamine 2000 reagent following the manufacture's instruction. These experiments were carried out independently three times.

\section{Real time RT-PCR}

Total RNA was isolated from cells with Trizol reagent according to the manufacture's protocol (Invitrogen, Carlsbad, CA, USA) and was reversely transcribed into cDNA with AMV reverse transcriptase (Promega). Real-time PCR was set up with the Stratagene Mx3000p (Agilent Technologies, Santa Clara, CA, USA) by using Brilliant ${ }^{\circ}$ II SYBR Green QPCR Master Mix (Agilent Technologies). PCR was performed at $95^{\circ} \mathrm{C}$ for $15 \mathrm{~s}$ and $60^{\circ} \mathrm{C}$ for $60 \mathrm{~s}$ for 40 cycles. Primer sequences were as follows: $\mathrm{ER} \alpha, 5^{\prime}$-TGCCCACTAC TCTGGAGAAC-3' (forward) and 5' -CCATAGCCATACT 
TCCCTTGTC-3' (reverse); Bmil, 5' -AATTAGTTCCAGG GCTTTTCAA-3' (forward) and 5'-CTTCATCTGCAACC TCTCCTCTAT- $3^{\prime}$ (reverse); p16 $6^{\mathrm{INK} 4 \mathrm{a}}, 5^{\prime}$-GCTGCCCAAC GCACCGAATA-3' (forward) and 5'-ACCACCAGCGTGT CCAGGAA-3' (reverse); $\beta$-actin, 5'-ATCATGTTTGAGA CCTTCAACA-3' (forward) and 5'-CATCTCTTGCTCGA AGTC-3'(reverse). The $\beta$-actin from the same extracts was used as an internal control. The amount of ER $\alpha$, Bmil and $\mathrm{p} 16^{\mathrm{INK} 4 \mathrm{a}}$ were normalized to the $\beta$-actin value. Data were calculated from the mean of three experiments.

\section{Reporter construction and luciferase assay}

Genomic DNA was prepared using standard molecular techniques and was used as a template for amplification of the Bmi1 promoter [GenBank: NC_000010. 10.3] with three different pairs of primers as follows: region $1(-1158 \sim+36)$ sense sequence 5 '-CTTCAG CTGAACCACCGTTTGTG-3' and antisense sequence 5'-GCCAAGCTTCTGCCTCTCATACTACG-3'; region $2(-850 \sim+36)$ sense sequence $5^{\prime}$-GTTCAGCTGCTAG ATAGGAGTAGTGTG-3' and antisense sequence $5^{\prime}$ GCCAAGCTTCTGCCTCTCATACTACG-3'; region 3 $(-203 \sim+36)$ sense sequence 5'-GTTCAGCTGCCCT TAAGGAATGAGG-3' and antisense sequence $5^{\prime}$-GCC AAGCTTCTGCCTCTCATACTACG-3'; and region 4 $(-116 \sim+36)$ sense sequence $5^{\prime}$-GTTCAGCTGTCAGT TTCCACTCTG-3' and antisense sequence 5'-GCCAAG CTTCTGCCTCTCATACTACG-3'. PCR products were digested with appropriate restriction enzymes and subcloned into multiple SmaI-Hind III cloning sites on the pGL2-Basic plasmid (Promega) and sequenced, generating pGL2-1200, pGL2-900, pGL2-460, pGL2-240 and pGL2152 (Figure 1B).

Transfection was performed in 24-well plates $\left(1 \times 10^{5}\right.$ cells/per well) using Lipofectamine 2000 reagent with $200 \mathrm{ng}$ of reporter (or pGL2-basic) and $2 \mathrm{ng}$ of pRL-SVRenilla reference vector (Promega). Alternatively, in some experiments $200 \mathrm{ng}$ pcDNA3.1-ER $\alpha$ with $200 \mathrm{ng}$ of reporter (or pGL2-basic) and 2 ng of pRL-SV-Renilla reference vector were co-transfected. Protein lysates were prepared from post-transfected cells, and luciferase activities were measured with the Dual-Luciferase Reporter Assay System (Promega) using a MicroBeta TriLux Liquid Scintillation and Luminescence Counter (Perkin-Elmer, Waltham, MA, USA). Firefly luciferase activity was normalized to Renilla luciferase activity and presented as a ratio (relative luciferase activity). All experiments were performed independently at least three times.

\section{Chromatin immunoprecipitation (ChIP)}

MCF-7, MDA-MB-231 and 231/ER $\alpha$ cells were held in steroid starvation for 3 days and then treated with $10^{-8} \mathrm{M}$ E2 or vehicle $(12 \mathrm{~h})$ at $80 \%$ confluence. ChIP was performed as previously described [26]. Briefly, $5 \times 10^{6}$ cells per ChIP assay were cross-linked with $1 \%$ formaldehyde for $10 \mathrm{~min}$ at $37^{\circ} \mathrm{C}$ and then quenched with $125 \mathrm{mM}$ glycine. Cells were washed with cold PBS and scraped into PBS with protease inhibitors (Roche, Indianapolis, IN, USA). Cell pellets were resuspended in ChIP lysis buffer (1\% SDS, $10 \mathrm{mM}$ EDTA, $50 \mathrm{mM}$ Tris-HCl. $\mathrm{pH}$ 8.1) and sonicated with an Ultrasonic Homogenizer (Cole-Parmer, Chicago, IL, USA) to produce sheared chromatin with an average length of $500 \mathrm{bp}$. The sheared chromatin was subjected to a clarification spin and the supernatant was then used for ChIP or reserved for analysis of "Input". Anti-ER $\alpha$ antibody (Epitomics) was used and normal rabbit IgG (Sigma) was used as negative control. Primers for the ChIP-PCR assay were as follows: ChIP primers $(-327 \sim-172)$ for sense: 5 '-CGTGTGGCGCT GTGGAGAAATGTCT-3' and antisense: 5'-GGGTC ACGTGCTCCCCTCATTCCTT-3'; ChIP negative control primers $(-2647 \sim-2523)$ sense: 5' -GTGGAAAG TAGAGCCATTCT-3' and antisense: 5' -AAACATCCG TTATATGAGGG-3'.

\section{Results}

The expression of Bmi1 strongly correlated with ERa status in breast cancer

Expression of Bmil was found in most non-neoplastic tubular epithelial cells in breast tissue, and was also found in a large proportion of breast cancer $(79.35 \%, 73 / 92)$ by immunohistochemistry (Figure 2). Positive staining for Bmi1 was analyzed for comparison with other routine markers of breast cancer including ER $\alpha$, PR, HER2, and Ki-67. The extent of positive staining for Bmil overlapping ER $\alpha$-positivity was striking $(98.33 \%, 59 / 60)$, and this was much less extensive overlap in the ER $\alpha$-negative group (43.75\%, 14/32). Loss of Bmil expression was extraordinarily rare in the $E R \alpha$-positive group $(1.67 \%, 1 / 60)$ as compared to the ER $\alpha$-negative group $(56.25 \%, 18 / 32)$. Similarly, ER $\alpha$ positivity was found in $80.82 \%(59 / 73)$ of the Bmi1 positive group and in $5.26 \%(1 / 19)$ of the Bmi1 negative group. These data indicate that the expression of Bmil is positively correlated with estrogen receptor $\alpha$ status $(P<0.0001)$ (Table 1$)$. And expectedly, Bmil showed similar rates of positivity in both Luminal-A $(100.00 \%, 28$ / $28)$ and Luminal-B $(96.15 \%, 25 / 26)(P=0.481)$ (Table 2$)$. To further evaluate expression of Bmil, its target gene p16 ${ }^{\mathrm{INK} 4 \mathrm{a}}$ was analyzed in both Bmi1-positive and negative groups with immunohistochemistry, and staining results confirmed Bmi1 status (see ER $\alpha$-coupled Bmil regulatory signature in breast cancer in Results).

Since Bmil and ER $\alpha$ are both transcription regulators, this marked overlap of expression suggested that Bmil and ER $\alpha$ could mutually regulate each other in a direct way. At the same time, detailed analysis showed that the rate of Bmil positivity in the ER $\alpha$ positive group was 

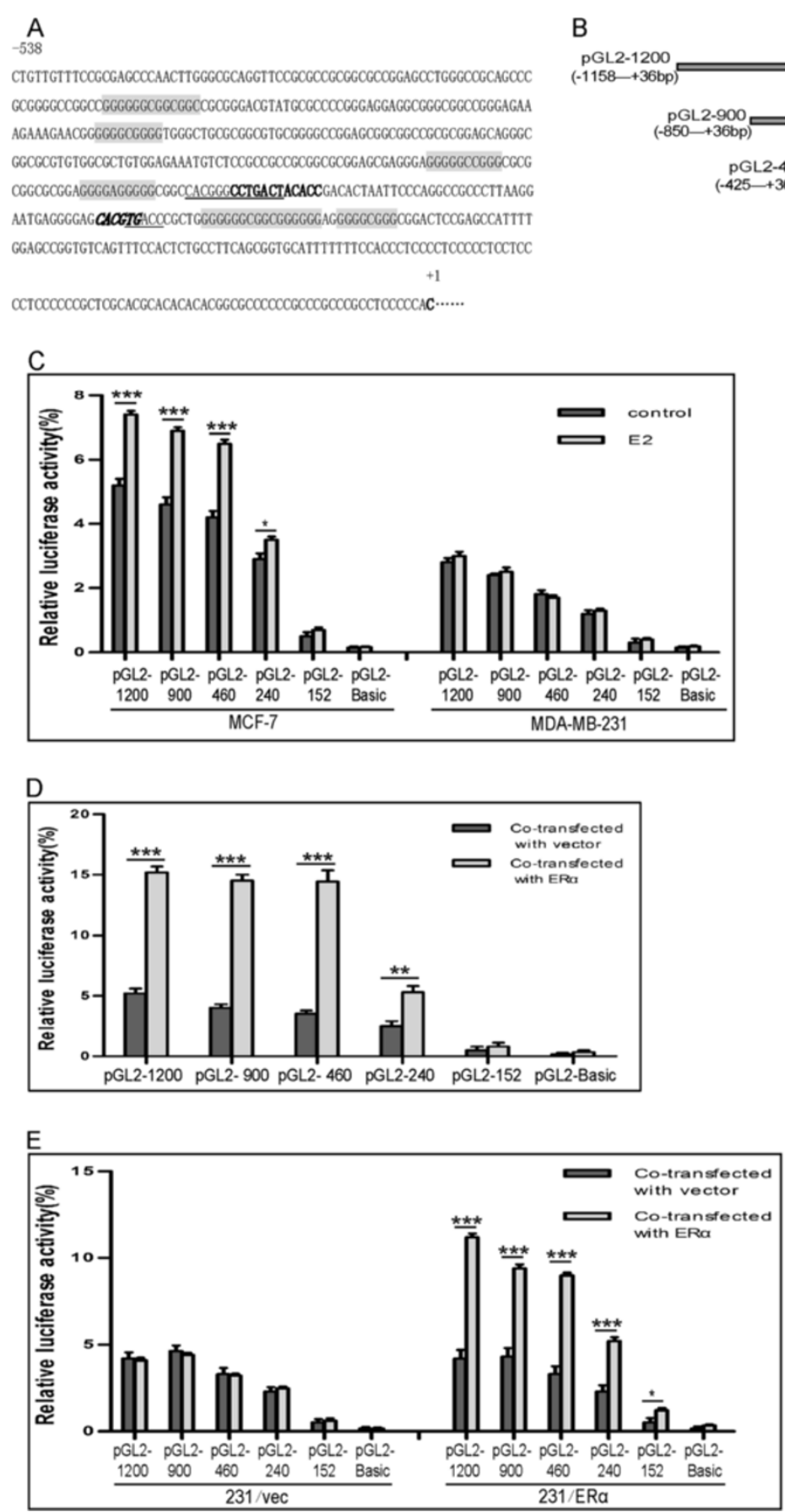

Figure 1 (See legend on next page.) 
(See figure on previous page.)

Figure 1 Effects of ERa on the transcriptional activity of Bmi1 promoter. (A) The composition of the Bmi1 core promoter. The transcription element E-box is in italics, AP-1 is in boldface, several Sp-1 s are in the shadow box, and the putative ERa response elements (ERE) are underlined. +1 indicates the transcription start. (B) Luciferase reporter construction. A series of reporters including pGL2-1200, pGL2-900, pGL2-460, pGL2-240 and pGL2-152 were constructed spanning the sequence $+36 \mathrm{nt}$ to $-1158 \mathrm{nt}$ of the Bmi1 promoter, and the two putative EREs were in black box. (C) The transcriptional activity of the Bmi1 gene promoter in ERa-positive or -negative breast cancer cells. MCF-7 and MDA-MB-231 cells were cultured in phenol red free medium containing 10\% charcoal stripped FBS and transiently transfected with 200 ng each of empty pGL2-basic, pGL2-1200, pGL2-900, pGL2-460. pGL2-240 or pGL2-152 in the absence or presence of $10^{-8} \mathrm{M}$ E2, respectively. Cells were harvested $48 \mathrm{~h}$ after transfection and assayed for luciferase activity. (D) The transfection of ERa enhanced transcriptional activity of the Bmi1 promoter. MCF-7 cells were co-transfected with 200 ng each of reporter plasmids and 200 ng of ERa expression plasmid (pcDNA3.1-ERa) or pcDNA3.1 empty vector. Cells were harvested $48 \mathrm{~h}$ after transfection and assayed for luciferase activity. (E) The reactivation of Bmi 1 promoter in ERa-restored ERa-negative cells. ERa-restored MDA-MB-231 cells (231/ERa) or their control 231/vec cells were transfected with 200 ng of each of the reporter plasmids. The relative luciferase activity values are corrected for co-transfected Renilla activity. And the experiments were repeated at least three times independently and all data are shown by bars as means $\pm \mathrm{SD}\left({ }^{*} \mathrm{P}<0.05,{ }^{* *} \mathrm{P}<0.01,{ }^{* * *} \mathrm{P}<0.001\right.$ when compared with the control groups, respectively).

98.33\% (59/60), which was much higher than the positive rate of $\mathrm{ER} \alpha$ in the Bmil positive group $(80.82 \%$, $59 / 73)$. In addition, in view of the fact that Bmil is a transcription repressor, it seemed likely that ER $\alpha$ positively regulates the expression of Bmil.

Taken together, these data suggested there is a correlation between the expression of Bmi1 and ER $\alpha$ status and raised the possibility that ER $\alpha$ affects Bmil expression.

\section{ERa specifically regulates the expression of Bmi1 in breast cancer cells}

These data raised the possibility that ER $\alpha$ influences Bmi1 expression, however, to rule out the possibility that Bmi1 affects ER $\alpha$ expression, we repeatedly transiently transfected MCF-7 cells with ectopic Bmil, and confirmed that introduction of Bmil has no effect on the expression of ER $\alpha$ (Figure 3A).

To determine whether Bmi1 is regulated by ER $\alpha$, two breast cancer cell lines, ER $\alpha$-positive MCF-7 and ER $\alpha$ negative MDA-MB-231, were selected and treated with $10^{-8} \mathrm{M} E R \alpha$ ligand E2. In the presence of E2 $\left(10^{-8} \mathrm{M}\right)$, the expression of Bmil in MCF-7 cells was enhanced in a timedependent manner, peaking at $12 \mathrm{~h}$ and persisting for at least $36 \mathrm{~h}$. At the same time, the level of $\mathrm{p} 16^{\mathrm{INK} 4 \mathrm{a}}$ declined over a time course similar to that of Bmil (Figure 3B). Conversely, the expression of Bmi1 in ER $\alpha$ negative MDAMB-231 cells showed no significant response to the addition of $10^{-8} \mathrm{M}$ E2 (Figure 3C). Moreover, the E2stimulated expression of Bmi1 and consequent suppression of $\mathrm{p} 16^{\mathrm{INK} 4 \mathrm{a}}$ in MCF-7 cells was antagonized by the antagonist $\mathrm{OHT}$ at $10^{-6} \mathrm{M}$ (Figure 3D).

To further evaluate stimulation of Bmil expression by $\mathrm{ER} \alpha$, ectopic $\mathrm{ER} \alpha$ (pcDNA3.1-ER $\alpha$ ) was stably introduced into the ER $\alpha$-negative MDA-MB-231 cells (Figure 4A). As a result, the ER $\alpha$-restored MDA-MB-231 cells (231/ER $\alpha$ ) displayed elevation of Bmil expression in a time dependent manner in the presence of $10^{-8} \mathrm{M} \mathrm{E} 2$ (Figure 4B), which was also inhibited by the addition of $10^{-6} \mathrm{M}$ OHT (Figure 4C). Conversely, the expression of Bmil in
ER $\alpha$ negative 231/vec cells showed no significant response to the addition of $10^{-8} \mathrm{M} \mathrm{E2}$ (Figure 4D) and $10^{-6} \mathrm{M}$ OHT (Figure 4E).

Taking another approach, three pairs of siRNAs against different sequences of ER $\alpha$ were synthesized and transiently transfected into MCF-7 cells, and after $72 \mathrm{~h}$ the effect of ER $\alpha$ silencing was confirmed by western blot. The level of ER $\alpha$ protein was markedly reduced by siRNA3 (Figure 5A). ER $\alpha$ depleted MCF-7 cells showed a decrease in expression of Bmi1, but expression of $\mathrm{p} 16^{\mathrm{INK} 4 \mathrm{a}}$ increased as compared to the controls (NS group) (Figure 5B).

In summary, these results implied that ER $\alpha$ may specifically stimulate the functional expression of Bmi1.

ERa up-regulated Bmi1 expression at the transcription level As a classic steroid hormonal receptor, ER $\alpha$ generally regulates its target genes at the transcriptional level. The sequences of the Bmil promoter were therefore retrieved and bio-informatically analyzed. The Bmi1 promoter contains a series of GC-rich sequences close to its transcription start site, and several putative transcription factor elements including AP-1 (activator protein-1) and Sp-1 (specificity protein-1) in addition to one confirmed E-box (enhancer-box) [13,27,28], in which two putative half estrogen responsive elements (ERE) were found to overlap with the AP-1 and Sp-1 elements (Figure 1A). Various regions which encompassed the Bmil up-stream sequences according to the database sequences were amplified and a series of luciferase reporters were generated, including pGL2-1200, pGL2-900, pGL2-460, pGL2240 and pGL2-152 (Figure 1B).

With a dual reporter system, MCF-7 and MDA-MB231 cells were transiently transfected with pGL2-1200, pGL2-900, pGL2-460, pGL2-240 or pGL2-152 together with a pRL-SV-Renilla luciferase reference vector. As expected, MCF-7 and MDA-MB-231 cells showed significantly different reporter activities (Figure 1C). With treatment of E2 $\left(10^{-8} \mathrm{M}\right)$, the reporter activity of the Bmi1 promoter constructs was slightly increased in 
(See figure on previous page.)

Figure 2 Expression of ERa, Bmi1, p16 ${ }^{\text {INK4a }}$, PR, cyclin D1, pRB and Ki-67 in breast carcinoma. The left column: the representative images for staining of ERa, Bmi1, p16 ${ }^{\mathrm{INK} 4 a}$, PR, cyclin D1, pRB and Ki-67 in non-cancerous breast tissue. The middle column: the representative images for ERa positive breast cancer with Bmi1 positive and p16 ${ }^{\text {INK4a }}$ negative. The various positive staining of PR, cyclin D1, pRB and low Ki-67 index are presented. The right column was representative images for ERa negative breast cancer with negative Bmi 1 but diffuse staining of p16 ${ }^{\text {INK4a }}$. The various staining of PR, cyclin D1, pRB and high Ki-67 index are presented, respectively. (Hematoxylin /DAB, $\times 400$ ).

MCF-7 but not in MDA-MB-231 cells (Figure 1C). However, upon co-transfection of the luciferase reporters with pcDNA3.1-ER $\alpha$ into MCF-7 cells, there was an overall increase in transcription activity of the Bmi1 promoter (Figure 1D). In order to observe the specificity of the effect of $\mathrm{ER} \alpha$, the Bmi1 promoter reporters were transfected into ER $\alpha$-restored MDA-MB-231 cells (231/ER $\alpha)$, and showed increased transcription activity as compared to empty vector-transfected MDA-MB-231 cells (231/vec) (Figure 1E). These results proved that ER $\alpha$ could activate the transcription activity of the Bmil core promoter.

We further tested for ER $\alpha$ binding on the Bmil promoter in MCF-7, MDA-MB-231 and 231/ER $\alpha$ cell lines with ChIP. Following treatment of the cells with $10^{-8} \mathrm{M}$ E2, DNA immunoprecipitated with anti-ER $\alpha$ antibody was amplified using Bmil promoter primers to evaluate the interaction of $\mathrm{ER} \alpha$ with the $B m i 1$ promoter at $-327 \sim-172 \mathrm{bp}$ (Figure 6). Results confirmed that $E R \alpha$ can interact with the up-stream element of the Bmi1 promoter.

\section{ERa-coupled Bmi1 regulatory pathway in breast cancer} To evaluate the functional role of the ER $\alpha$-coupled Bmi1 regulatory pathway in breast cancer, the expression of

Table 1 The correlation of Bmi1 or p16 ${ }^{\text {INK4a }}$ expression with other commonly used markers of breast cancer

\begin{tabular}{|c|c|c|c|c|c|c|}
\hline & \multicolumn{2}{|c|}{ Bmi1 } & \multirow[t]{2}{*}{$P$ value } & \multicolumn{2}{|c|}{$\mathrm{p} 16^{\mathrm{INK4a}}$} & \multirow[t]{2}{*}{$P$ value } \\
\hline & - & + & & - & + & \\
\hline ERa & & & $<0.0001$ & & & $<0.0001$ \\
\hline- & 18 & 14 & & 9 & 23 & \\
\hline+ & 1 & 59 & & 56 & 4 & \\
\hline PR & & & $<0.0001$ & & & $<0.0001$ \\
\hline- & 17 & 16 & & 11 & 22 & \\
\hline+ & 2 & 57 & & 54 & 5 & \\
\hline Ki-67 & & & $<0.0001$ & & & $<0.0001$ \\
\hline 0-13\% & 3 & 35 & & 33 & 5 & \\
\hline $14-29 \%$ & 1 & 15 & & 15 & 1 & \\
\hline $30-49 \%$ & 4 & 14 & & 11 & 7 & \\
\hline 50-100\% & 11 & 9 & & 6 & 14 & \\
\hline Bmi1 & & & - & & & $<0.0001$ \\
\hline - & - & - & & 1 & 18 & \\
\hline+ & - & - & & 64 & 9 & \\
\hline
\end{tabular}

Bold face representing significant data $(P<0.05)$. p16 ${ }^{\text {INK4a }}$ or cyclin D1 which are target genes of Bmi1 and $\mathrm{ER} \alpha$ [29] respectively, was measured and their correlation with other indices of breast cancer was analyzed.

\section{Down-regulation of ERa and Bmi1 correlated with aberrant} expression of $p 16^{\text {INK4a }}$

In normal tissues adjacent to breast cancer, $\mathrm{p} 16^{\mathrm{INK} 4 \mathrm{a}}$ was expressed only in nuclei of occasional cells (Figure 2), while p $16^{\text {INK4a }}$ showed aberrant staining of tumor cells in $29.35 \%(27 / 92)$ of breast cancers, and this positive staining was generally present in both the nuclei and cytoplasm (Figure 2). Even in some cases, staining was present mainly in the cytoplasm with decreased or absent nuclear staining. Aberrant staining for $\mathrm{p} 16^{\mathrm{INK} 4 \mathrm{a}}$ was found in $71.88 \%(23 / 32)$ of $E R \alpha$ negative cases out of a total of 92 cases of invasive carcinoma, compared to ER $\alpha$ positive tumors $(6.67 \%, 4 / 60)$. Similarly, p16 ${ }^{\text {INK4a }}$ was frequently expressed in progesterone receptor (PR) negative tumors $(66.67 \%, 22 / 33)$ and was positive in only a small number of cases in the PR positive group $(8.47 \%$, $5 / 59)$. p $16^{\mathrm{INK} 4 \mathrm{a}}$ expression showed a strong inverse correlation with ER $\alpha$ and PR expression status $(P<0.0001$, $P<0.0001$ ) (Table 1 ), indicating that aberrant expression of $\mathrm{p} 16^{\mathrm{INK} 4 \mathrm{a}}$ is associated with loss of hormone receptors. Similarly, Bmi1 was positive in most of the $\mathrm{p} 16^{\text {INK4a }}$ negative group $(98.46 \%, 64 / 65)$, while Bmi1 negativity was found frequently with aberrant staining of p16 ${ }^{\text {INK4a }}$ $(66.76 \%, 18 / 27)$. There was a significant negative correlation of Bmi1 with $\mathrm{p} 16^{\text {INK4a }}(P<0.0001)$ (Table 1$)$, demonstrating aberrant expression of $\mathrm{p} 16^{\mathrm{INK} 4 \mathrm{a}}$ is associated with reduced Bmil expression.

Table 2 The aberrant expression of $\mathrm{p} 16^{\text {INK4a }}$ or Bmi1 in molecular subtypes of breast cancer

\begin{tabular}{ccccccc}
\hline Subtypes & \multicolumn{2}{c}{$\mathbf{p 1 6 ^ { \text { INK4a } }}$} & P value & \multicolumn{2}{c}{ Bmi1 } & \multirow{2}{*}{$\boldsymbol{P}$ value } \\
\cline { 2 - 4 } & - & + & & - & + & \\
\hline LA & 28 & 0 & $<\mathbf{0 . 0 0 0 1}$ & 0 & 28 & $<0.0001$ \\
LB & 22 & 4 & & 1 & 25 & \\
LHP & 8 & 0 & & 0 & 8 & \\
HP & 5 & 11 & & 7 & 9 & \\
TNBC & 2 & 12 & & 11 & 3 & \\
Total & 65 & 27 & & 19 & 73 &
\end{tabular}

Abbreviations: LA Luminal-A, LB Luminal-B, LHP Luminal-HER2-Positive, HP HER2-Positive (HER2-enriched), TNBC Triple Negative Breast Cancer. Bold face representing significant data $(P<0.05)$. 
A



B'

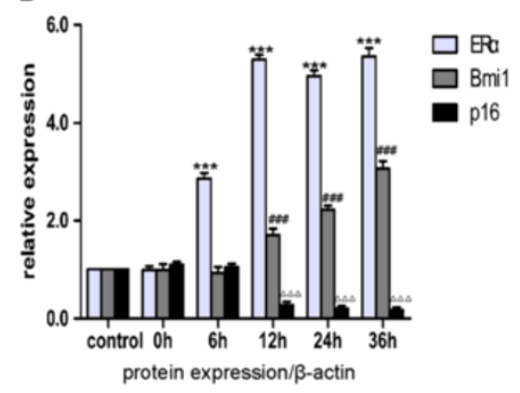

C
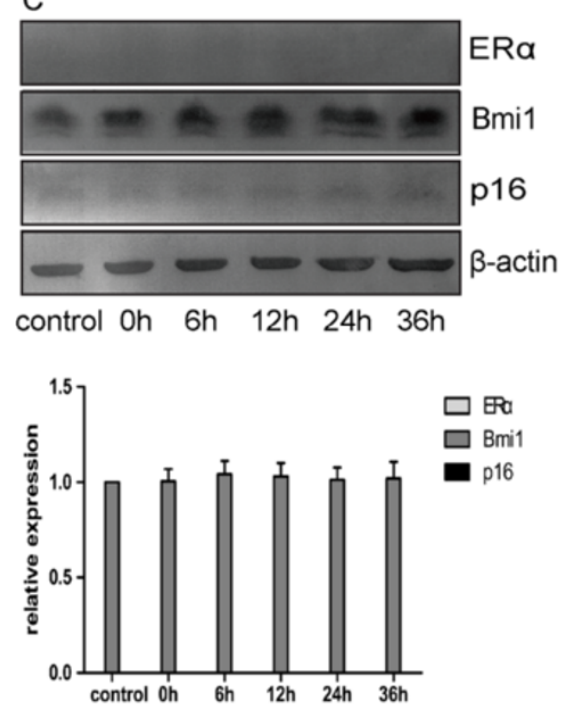

\section{B}

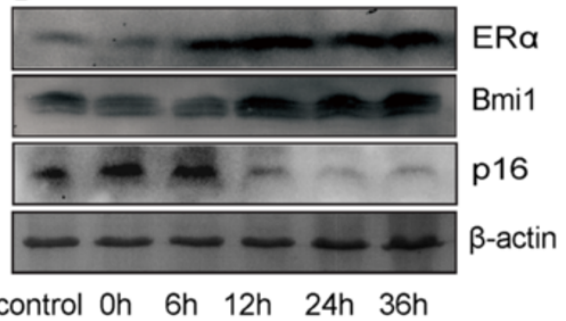

control Oh $6 \mathrm{~h} \quad 12 \mathrm{~h} \quad 24 \mathrm{~h} 36 \mathrm{~h}$

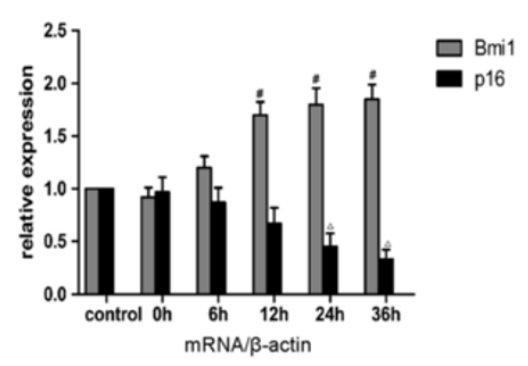

D
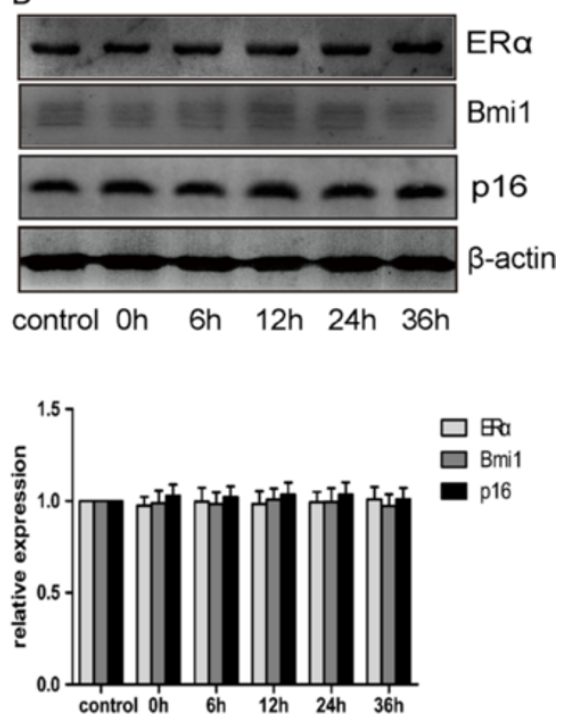

Figure 3 Expression of Bmi1 was stimulated by E2 in ERa-positive breast cancer cells. (A) Effect of Bmi1 ectopic expression on ERa protein in MCF-7 cells. MCF-7 cells were transiently transfected with Bmi1 (pcD-Bmi1), an empty vector, or transfection reagent (control). Cells were collected after $48 \mathrm{~h}$ of transfection and analyzed for Bmi1, ERa and $\beta$-actin expression with Western blot. This image represents one of three experiments. (B-D) Expression of Bmi1 was stimulated by E2 in ERa-positive breast cancer cells. ERa-positive MCF-7 (B) and ERa-negative MDA-MB-231 (C) cell lines were cultured in phenol red free medium containing $10 \%$ charcoal striped FBS for $72 \mathrm{~h}$ and $10^{-8} \mathrm{M}$ E2 was added. At indicated time points, cells were collected and analyzed for Bmi1, ERa, p16 $6^{\text {INK4a }}$ and $\beta$-actin expression by Western blot and real time RT-PCR (B', right panel).

(D) MCF-7 cells were treated with $10^{-6} \mathrm{M}$ OHT in the presence of E2 and Western blot was performed. $\beta$-actin was used as loading control. Quantitative analyses of ERa, Bmi1 and $16^{\mathrm{INK} 4 \mathrm{a}}$ are presented. All data were obtained from three independent experiments and are shown by bars as means \pm SD

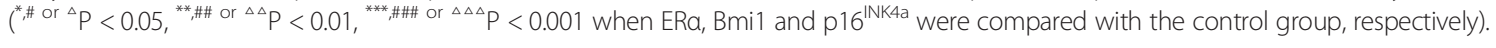

To gain further insight into the pathologic implications of loss of ER $\alpha$-coupled Bmi1 inducing abnormal p16 ${ }^{\text {INK4a }}$ expression, the relationships between aberrant p16 ${ }^{\mathrm{INK} 4 \mathrm{a}}$ expression and other factors in breast cancer such as HER2 and Ki-67 were analyzed. p16 ${ }^{\text {INK4a }}$ expression was found in a majority of triple-negative breast carcinomas (TNBC) $(85.71 \%, 12 / 14)$ and HER2enriched carcinomas $(68.75 \%, 11 / 16)$, whereas it was less frequent in Luminal-B type tumors $(15.38 \%, 4 / 26)$ and was not found in Luminal-A tumor $(0.00 \%, 0 / 28)$ or in Luminal-HER2-Positive tumors $(0.00 \%, 0 / 8)$. p16 ${ }^{\text {INK4a }}$ positivity in triple negative breast cancer and 


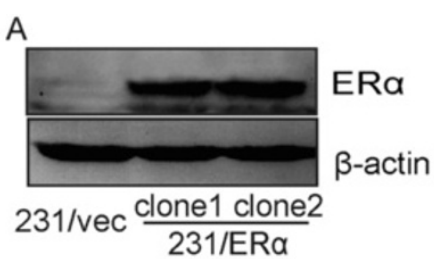

$\mathrm{B}^{\prime}$

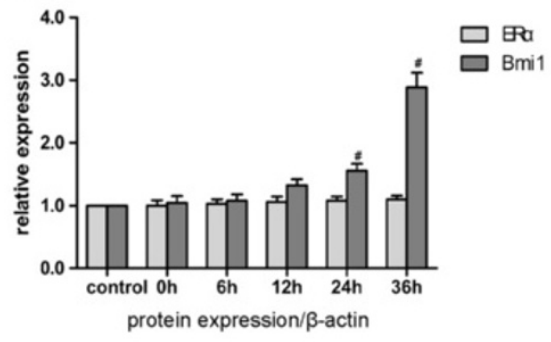

C

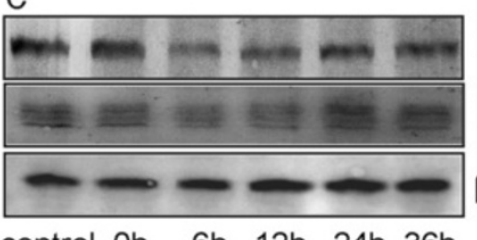

control Oh 6h 12h 24h 36h

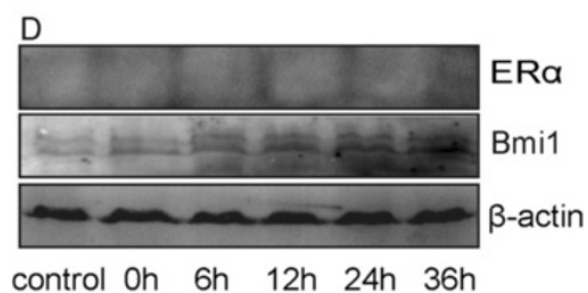

E



B

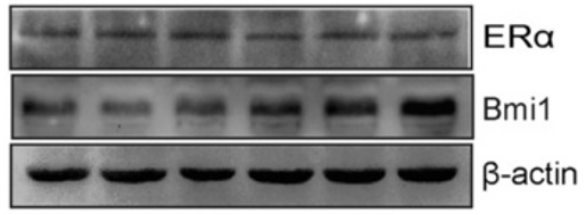

control Oh $6 \mathrm{~h} \quad 12 \mathrm{~h} \quad 24 \mathrm{~h} 36 \mathrm{~h}$
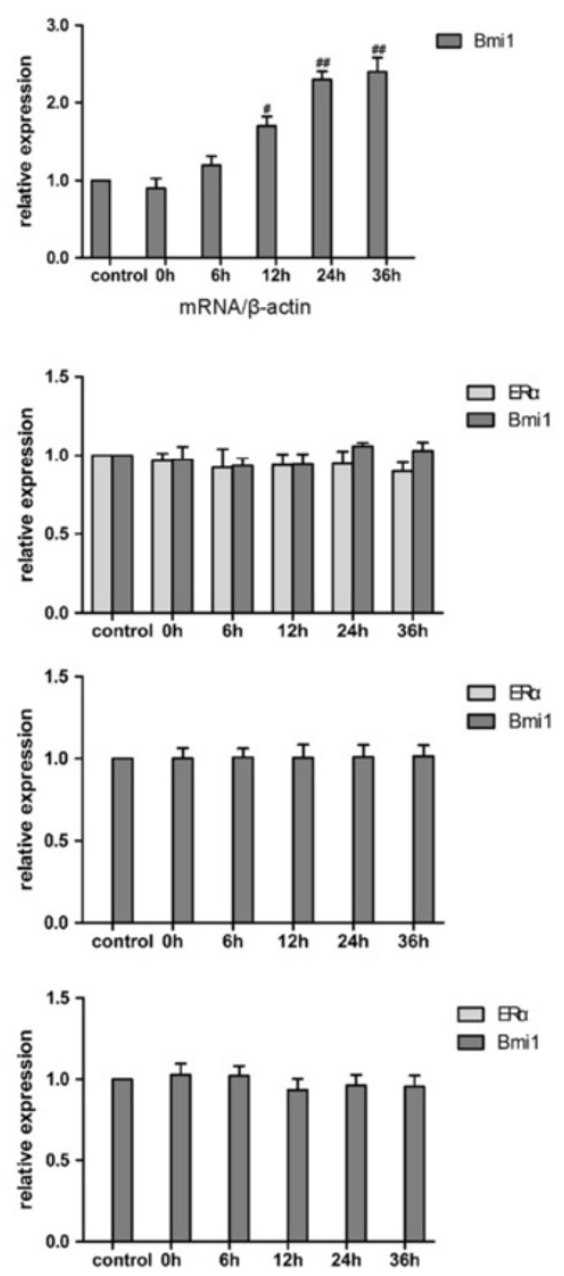

Figure 4 Expression of Bmi1 was stimulated by E2 in ERa-restored breast cancer cells. (A) 231/ERa and 231/vec were generated by stable transfection of MDA-MB-231 cells by ERa or empty vector, respectively. (B) 231/ERa and (D) 231/vec cells were stimulated with 10 ${ }^{-8} \mathrm{M}$ E2, and $10^{-6} \mathrm{M}$ OHT was added at the same time, (C and E). At indicated time, cells were collected and analyzed for Bmi1, ERa and $\beta$-actin expression by Western blot and real time RT-PCR ( $\mathbf{B}^{\prime}$, right panel). $\beta$-actin was used as loading control. Quantitative analyses of ERa, Bmi1 and p16 $6^{\text {INK4a }}$ are presented. All data were obtained from three independent experiments and are shown by bars as means \pm SD ( ${ }^{P} P<0.05$ when Bmi 1 was compared with the control group).

HER2-enriched subtypes showed a marked statistical difference from tumors in the other three groups $(P<$ 0.0001) (Table 2). This specific distribution of aberrant p16 ${ }^{\text {INK4a }}$ expression over the various molecular subtypes pointed strongly to a relationship with hormone receptor status.

The Ki-67 index is a chief factor for distinguishing the Luminal-A and Luminal-B subtypes, so the relationship of p16 ${ }^{\mathrm{INK} 4 \mathrm{a}}$ and Ki-67 expression was analyzed. For this purpose, cases were classified into four Ki-67 expression index groups which included 0-13\%, 14\%-29\%, 30\%-49\% and $50-100 \%$. The positivity rates of $\mathrm{p} 16^{\mathrm{INK} 4 \mathrm{a}}$ in these four groups were $13.16 \%$ (5/38), 6.25\% (1/16), $38.89 \%$ $(7 / 18)$ and $70.00 \%(14 / 20)$, respectively. This result demonstrated strong correlation of aberrant expression of p16 ${ }^{\mathrm{INK} 4 \mathrm{a}}$ with the Ki-67 index $(P<0.0001)$ (Table 1$)$. 

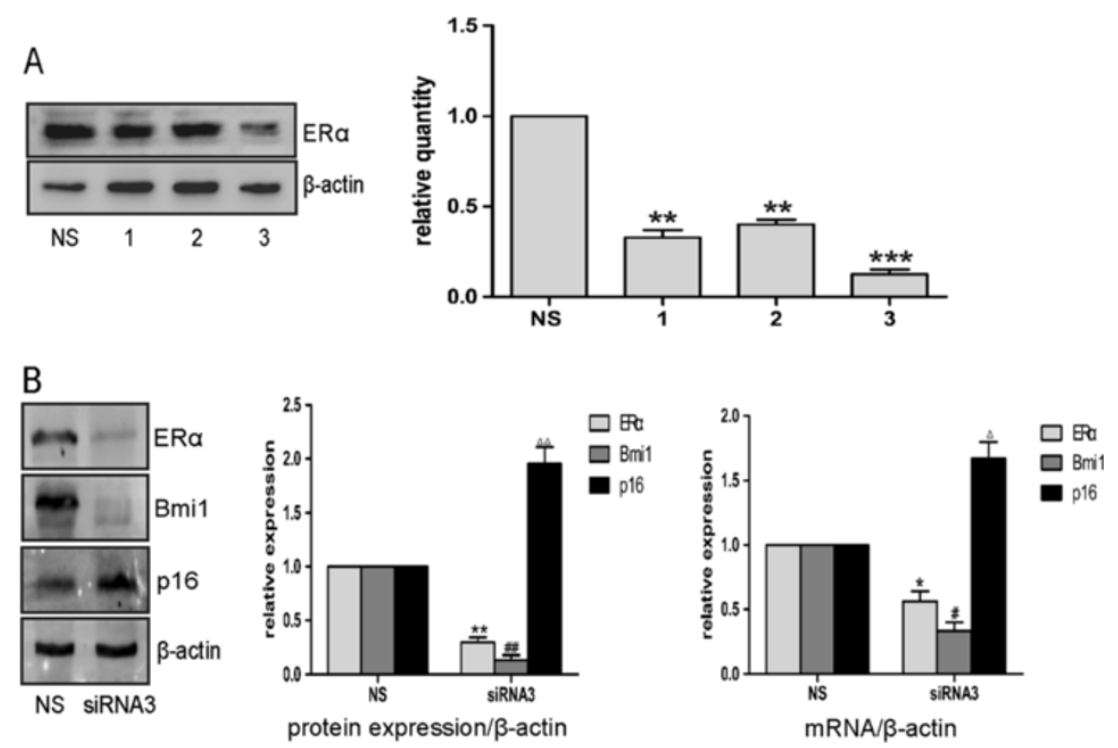

Figure 5 Depletion of ERa decreased the level of Bmi1 and its E2 response. (A) MCF-7 cells were transiently transfected with three sets of siRNAs specific for ERa (siRNA1, siRNA2, siRNA3) or with a control smart pool siRNA (NS), and $72 \mathrm{~h}$ after transfection cells were analyzed by Western blot (left panel). Quantitative analyses of ERa protein expression by the three siRNAs are presented (right panel). (B) MCF-7 cells were transiently transfected with siRNA3, and Bmi1, ERa and p16 ${ }^{\text {INK4a }}$ were analyzed by Western blot (left panel) and real time RT-PCR (right panel). $\beta$-actin was used as loading control. Quantitative analyses of ERa, Bmi1 and p1 $6^{\text {INK4a }}$ are presented (middle panel). Right panel: quantitative analyses on mRNA of ERa, Bmi1 and $\mathrm{p} 16^{\mathrm{INK} 4 \mathrm{a}}$. All data were obtained from three independent experiments and are shown by bars as means $\pm \mathrm{SD}\left({ }^{* *}, \ldots \#{ }^{\circ}{ }^{\Delta \Delta} \mathrm{P}<0.01,{ }^{* * *} \mathrm{P}<0.001\right.$ when $\mathrm{ERa}$, Bmi1 and p $16^{\text {INK4a }}$ were compared with the NS group, respectively).

\section{Expressions of ERa and Bmi1 correlated with activated cyclinD1}

Since cyclin D1 is a target of ER $\alpha$ [30], its expression was analyzed with respect to either ER $\alpha$ or Bmi1. Cyclin D1 was also positive more frequently in the ER $\alpha$ positive group $(90.00 \%, 54 / 60)$ (Figure 2), as compared to the ER $\alpha$ negative group $(50.00 \%, 16 / 32)$. Similarly, positive cyclin D1 was also found in most cases positive for Bmi1 $(86.30 \%, 63 / 73)$, while only a few cases of cyclin D1 were found in the Bmil negative group (36.84\%, 7/19). These results demonstrated a positive correlation between ER $\alpha$, or Bmi1 and cyclin D1 $(P<0.0001, P<0.0001)$. In addition, results showed that cyclin D1 positive cases predominated in the $\mathrm{p} 16^{\mathrm{INK} 4 \mathrm{a}}$-negative group (84.62\%, 55/ $65)$, as compared to $55.56 \%(15 / 27)$ of cases which were p16 ${ }^{\text {INK4a }}$-positive, showing an inverse correlation with aberrant expression of $\mathrm{p} 16^{\mathrm{INK} 4 \mathrm{a}}(P=0.003)$ (Table 3$)$.

\section{The aberrant expression of $p 16^{\text {INK4a }}$ or activated cyclin D1 did not correlate with $p R B$ status}

Phosphorylated $\mathrm{RB}$ ( $\mathrm{pRB}$ ), which is the inactivated form of the $\mathrm{RB}$ protein was analyzed, and there were no obvious differences in positive $\mathrm{p} 16^{\mathrm{INK} 4 \mathrm{a}}$ staining in $\mathrm{pRB}$ negative versus pRB positive tumors (16/62, 25.81\%; 11/30, 36.67\%) $(P=0.284)$ (Table 3$)$, indicating that $\mathrm{p} 16^{\mathrm{INK} 4 \mathrm{a}}$ expression has no correlation with $\mathrm{pRB}$ expression in this system (Figure 2).
Although the positivity rate for $\mathrm{pRB}$ in cyclin $\mathrm{D} 1$ positive cases $(35.71 \%, 25 / 70)$ was a little higher than that in cyclin D1 negative tumors $(22.73 \%, 5 / 22)$, the difference between pRB expression and the cyclin D1 status was not statistically different $(P=0.257)$ (Table 3$)$. In addition, $\mathrm{pRB}$ showed similar rates of positivity in both ER $\alpha$-positive $(30.00 \%, 18 / 60)$ and $E R \alpha$-negative cases $(37.50 \%, 12 / 32)$ $(P=0.465)$.

These data showed that neither aberrant $\mathrm{p} 16^{\mathrm{INK} 4 \mathrm{a}} \mathrm{ex}-$ pression nor activated cyclin D1 correlated with pRB in these breast cancers.

Taken together, these findings show the ER $\alpha$-coupled Bmi1 regulation pathway plays an important role in regulation of the genes and biological behavior of breast cancer. The expression of ER $\alpha$ usually increases both levels of Bmi1 and cyclin D1, while loss of ER $\alpha$-coupled Bmi1 activity may result in aberrant $\mathrm{p} 16^{\mathrm{INK} 4 \mathrm{a}}$ expression and is also generally consistent with a more aggressive breast cancer phenotype.

\section{Discussion}

The role of Bmil and the related functional network that serves in regulation of normal cells and cancer cells have been studied extensively in recent years. However, regulation of its expression, and especially the mechanism of its up-regulation in cancers, has rarely been explored $[14,15]$. To date, only E2F1 and MYCN have been shown to be direct activators of Bmil transcription in some kinds 

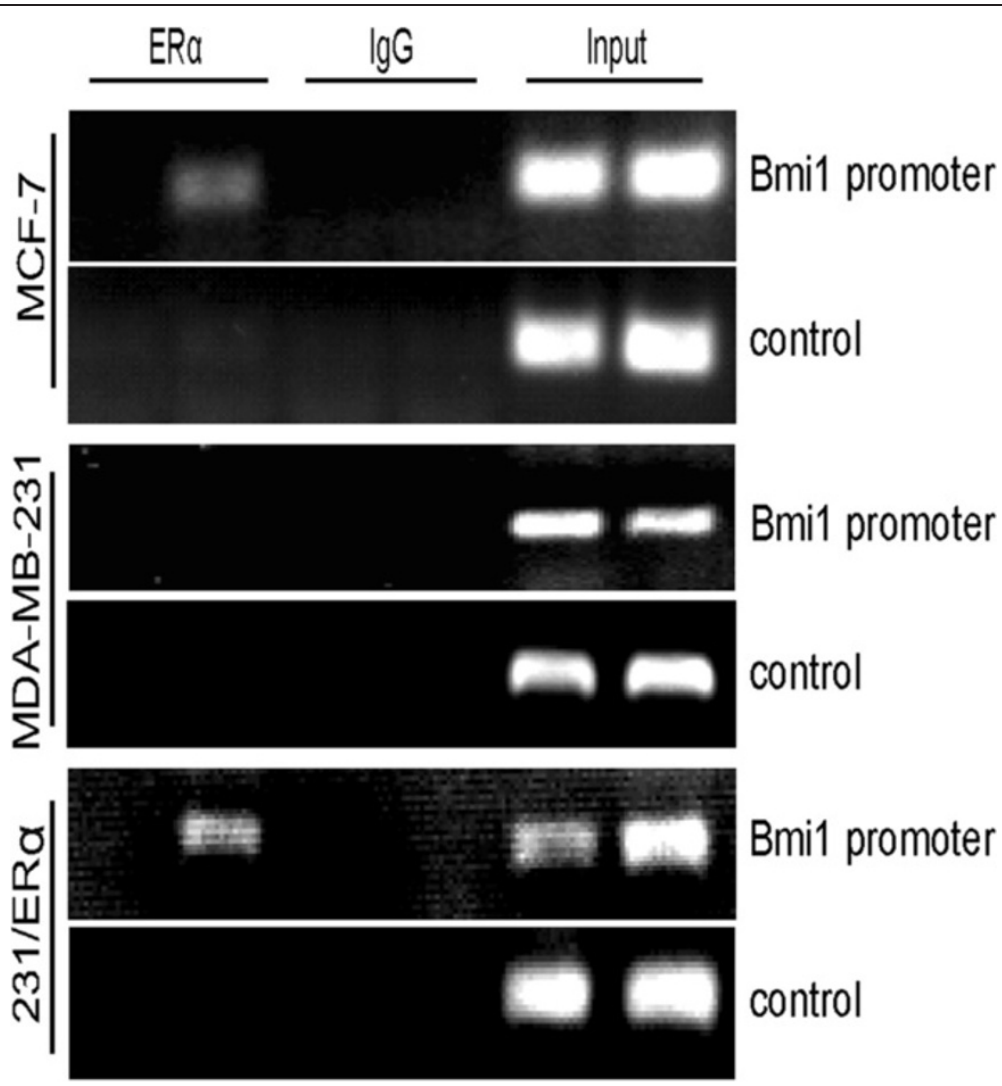

$\mathrm{E} 2:-\quad+\quad-\quad+\quad+$

Figure 6 Interaction of ERa and Bmi1 promoter. MCF-7, MDA-MB-231 and 231/ERa treated or untreated with $10^{-8}$ M E2 for $12 \mathrm{~h}$ were used for Chromatin immunoprecipitation (ChIP) analysis of the human Bmi1 promoter as described in Methods. ERa: anti-ERa antibody; IgG: rabbit lgG. Bmi1 promoter: region ( $-327 \mathrm{bp}$ to $-172 \mathrm{bp}$ ), and control: region ( $-2647 \mathrm{bp}$ to $-2523 \mathrm{bp})$. PCR products were resolved on a $2 \%$ agarose gel.

Table 3 Correlation of Cyclin D1 or pRB with ERa, Bmi1 and $p 16^{\text {INK4a }}$ expression in breast cancer

\begin{tabular}{|c|c|c|c|c|c|c|}
\hline & \multicolumn{2}{|c|}{ Cyclin D1 } & \multirow[t]{2}{*}{$P$ value } & \multicolumn{2}{|c|}{ pRB } & \multirow{2}{*}{$\begin{array}{c}P \\
\text { value }\end{array}$} \\
\hline & - & + & & - & + & \\
\hline ERa & & & $<0.0001$ & & & 0.465 \\
\hline - & 16 & 16 & & 20 & 12 & \\
\hline+ & 6 & 54 & & 42 & 18 & \\
\hline Bmi1 & & & $<0.0001$ & & & 0.659 \\
\hline - & 12 & 7 & & 12 & 7 & \\
\hline+ & 10 & 63 & & 50 & 23 & \\
\hline $\mathrm{p} 16^{\mathrm{INK} 4 a}$ & & & 0.003 & & & 0.284 \\
\hline- & 10 & 55 & & 46 & 19 & \\
\hline+ & 12 & 15 & & 16 & 11 & \\
\hline CyclinD1 & & & - & & & 0.257 \\
\hline- & - & - & & 17 & 5 & \\
\hline+ & - & - & & 45 & 25 & \\
\hline
\end{tabular}

Bold face representing significant data $(P<0.05)$. of cancers [31,32], and data regarding Bmi1 in tumor biology are far from complete. The over-expression of Bmi1 and its 11-gene signature has been defined in breast carcinoma [18]. At the same time, investigation has shown that Bmi1 expression is positively correlated with ER $\alpha$ status in breast cancer [33-35]. However, the direct interaction between these molecules has not been evaluated.

$\mathrm{ER} \alpha$ is extremely important in tumorigenesis in female sex organs, and its signaling pathway has thus been extensively investigated $[2,4]$. As a classic nuclear receptor, it translocates into the nucleus upon binding of estrogen to dimerized ER $\alpha$, and brings about activation of transcription of target genes via interaction with either ERE (estrogen responsive element) or other factors such as steroid receptor coactivator-1 (SRC-1), amplified in breast 1 (AIB1, also known as NCOA3) and E1A binding protein as well as p300/CREB binding protein (p300/CBP) $[6,36,37]$. The Bmi1 promoter is a classic house-keeping gene as it possesses such features as a non-TATA box, and it has GC-rich sequences, putative AP-1 and Sp-1 elements, and a functional E-box, which has been identified to interact with several transcription factors in regulation 
of cell proliferation, stress and senescence $[13,27,28]$. Our experiments demonstrated that ER $\alpha$ can activate the transcription of Bmi1 through directly interacting with its promoter. However, it is noteworthy that the magnitude of E2-inducing Bmi1 promoter activity appears to be much lower than that of E2-inducing Bmi1 protein levels in MCF7 cells. It is possible the Bmil promoter was weak in transcriptional activity in this study, as only low reporter activity was measured under basal conditions (Figure 1C). On the other hand, our study also revealed that overexpression of ER $\alpha$ markely stimulates transcription activity of the Bmi1 promoter as compared to the addition of E2 (Figure 1D, C). This may imply that the level of endogenous ER $\alpha$ more effectively affects the Bmi1 promoter than the concentration of cellular estrogen, which is consistent with the correlation found in the ER $\alpha$ status and the expression of Bmil in breast cancer. Although only two putative ERE elements were found to be embedded in the E-box and AP-1 consensus, it seemed that the upstream GC-rich sequences might be involved, since luciferase reporters spanning the -425 region were responsive to transfection of ER $\alpha$. Such results are similar to those which have been found in many ER $\alpha$ response genes, in which the GC-box, AP-1, -2 or Sp-1 are involved in ER $\alpha$ stimulation [36,37]. Despite the fact our investigation revealed that Bmil expression is determined by ER $\alpha$ status in breast cancer, it must be noted that nearly half of the cases with loss of ER $\alpha$ still expressed Bmil or cyclin D1 which is another ER $\alpha$ target gene $[29,38]$. This suggested the possibility that Bmi1 or cyclin D1 is induced mainly by $E R \alpha$. However if there is no expression of ER $\alpha, B m i 1$ may be induced by other factors such as E2F1 and MYC [31,32], both of which are usually expressed in cancers.

p16 ${ }^{\text {INK4a }}$-cyclinD1/RB consists of machinery for regulation of cell cycle progression. Several observations have suggested that inactivation of RB in the genome or in the phenotype can lead to abnormal expression of p16 ${ }^{\text {INK4a }}$ or cyclin D1, and promote cell cycle G1-S transition, resulting in sensitivity to loss of inhibition by $\mathrm{ER} \alpha$ in cancer cells $[39,40]$. Therefore, the disruption of p16 ${ }^{\mathrm{INK} 4 \mathrm{a}}$-cyclinD1/RB is believed to be a mechanism of resistance to endocrine therapy. However, our investigation showed that the expression of $\mathrm{p} 16^{\mathrm{INK} 4 \mathrm{a}}$ and cyclin D1 is largely dependent on the activity of the ER $\alpha$-coupled Bmi1 regulatory machinery, but not on $\mathrm{RB}$ status. In fact, although a preliminary report implied that $\mathrm{p} 16^{\text {INK4a }} / \mathrm{RB}$ is abnormally expressed in breast cancer [33], recent studies demonstrated that over-expression of $\mathrm{p} 16^{\mathrm{INK4a}}$ is indicative of a more undifferentiated malignant phenotype in mammary carcinoma, such as the basal-like phenotype, in which ER $\alpha$ is generally negative [34].

p16 $6^{\text {INK4a }}$ is a well known tumor suppressor and loss of its activity has been found widely in many kinds of human cancers [41]. However, its aberrant expression, in which p16 ${ }^{\mathrm{INK} 4 \mathrm{a}}$ not only over-expresses but also changes its subcellular distribution from nuclear to cytoplasmic, has also been found in some types of cancer, especially in precancerous cervical lesions and cancers [42]. In fact the aberrant expression of $\mathrm{p} 16^{\mathrm{INK4a}}$ has become a pathologic indicator of high tumor grade in cervical precancerous lesions [43]. As $\mathrm{p} 16^{\mathrm{INK} 4 \mathrm{a}}$ is a cyclin-dependent kinase inhibitor which is closely related to RB status, the aberrant expression of $\mathrm{p} 16^{\mathrm{INK4a}}$ is usually considered to be the result of compensation for RB inactivation, which occurs frequently in HPV-related cervical carcinogenesis $[41,42]$. Nevertheless, in this study we found a positive relationship between $\mathrm{p} 16^{\mathrm{INK} 4 \mathrm{a}}$ and Bmil instead of RB. In fact, $\mathrm{p} 16^{\mathrm{INK} 4 \mathrm{a}}$ has long been understood to be a target of Bmil, and a recent study has shown multiple Bmi1-interactive elements in the upstream of $p 16^{I N K 4 a}$ [44]. These results indicate that in contrast to cervical neoplasia, the disruption of the ER $\alpha$-Bmil pathway is most likely a primary cause of aberrant $\mathrm{p} 16^{\mathrm{INK} 4 \mathrm{a}}$ expression in breast cancer. In addition, aberrant expression of $\mathrm{p} 16^{\mathrm{INK4a}}$ may be a marker for ER $\alpha$ negative breast cancers such as the TNBC and HER2-enriched subtypes, and may also be useful in distinguishing HER2enriched from Luminal-B-HER2 positive breast tumors.

This study also demonstrates a positive relationship between ER $\alpha$-Bmi1 and cyclin D1 in ER $\alpha$-positive breast cancer. However, direct interaction exists only between cyclin D1 and ER $\alpha$ rather than Bmil, and the expression of cyclin D1 in breast cancer probably reflects the regulatory effect of ER $\alpha$. Therefore, the distribution of cyclin D1 in the various tumor subtypes was consistently found to be correlated with $\mathrm{ER} \alpha$ status.

However, considering the heterogeneity of breast cancer, the clinical cohort in this described research is relatively modest. Therefore, further investigation is necessary.

Nevertheless, more attention should be paid to the discovery that ER $\alpha$ regulated expression of Bmil, which could be a challenge to the general opinion of Bmil for its crucial role in regulating self-renewal of stem cells or cancer stem cells [13-15]. However, in a comprehensive analysis of Bmi1, Pietersen et al. also reveals a more intrinsic role of Bmil in development and homeostasis of mammary glands [45]. They demonstrate that Bmi1 expresses especially highly in luminal cells, which usually express hormone receptors. And knock-out of Bmi1 affects differentiation and proliferation of mammary stem cells but not reduces their number. In addition, loss of Bmi1 can induce premature lobuloalveolar differentiation, indicating that Bmil also affects more committed cells of mammary gland [45]. Combining the data with our results, we believe that there should be a close functional relationship between ER $\alpha$ and Bmil, which also be crucial in regulation of breast cancers, especially in luminal-type 
carcinomas. Therefore, the exact role of ER $\alpha$ coupled Bmi1 pathway in breast cancer need to be further explored.

\section{Conclusions}

This investigation revealed a regulatory relation between Bmi1 and ER $\alpha$, and demonstrated an ER $\alpha$-coupled Bmi1 signaling pathway in breast cancer. These results further reinforced the critical nature of the role of ER $\alpha$ in the development and treatment of breast cancer, and successful identification and description of ER $\alpha$ associated molecular events will provide a greater foundation for prevention and therapy of breast cancer.

\section{Additional file}

Additional file 1: Table S1. Clinical information of patients. Table S2.

Primary antibodies used in this study.

\section{Abbreviations}

ERa: Estrogen receptor a; RB: Retinoblastoma protein; CIN: Cervical intraepithelial neoplasia; HPV: Human papilloma virus; PCG: Polycomb group; PRC1: Polycomb repressor complex 1; IHC: Immunohistochemistry; WB: Western blot; E2: 17ß-estradiol; OHT: Hydroxytamoxifen; SiRNAs: Small interfering RNAs; ChIP: Chromatin immunoprecipitation; PR: Progesterone receptor; TNBC: Triple negative breast cancer; ERE: Estrogen responsive elements.

\section{Competing interests}

The authors declare that they have no competing interests.

\section{Authors' contributions}

$B Z, H W$ and $H L$ conceived and designed the experiments. HW, BZ and $H L$ performed experiments and drafted the manuscript. $H W, B Z, X L, J Z, H Z$, JM, $\mathrm{LH}, \mathrm{WH}$ and MAM interpretated and analyzed the data. $\mathrm{XL}, \mathrm{YZ}, \mathrm{HZ}$ and $\mathrm{SZ}$ contributed reagents/materials/analysis tools. All authors have read and approved the final manuscript.

\section{Acknowledgements}

This study was supported by the National Natural Science Foundation of China (\#81101998)

\section{Author details}

${ }^{1}$ Department of Pathology, Health Science Center of Peking University, 38 Xueyuan Road, Haidian District, Beijing 100191, China. ${ }^{2}$ Department of Pathology, Peking University First Hospital, Beijing 100034, China.

Received: 7 August 2013 Accepted: 19 February 2014 Published: 24 February 2014

\section{References}

1. Goldhirsch A, Wood W, Coates A, Gelber R, Thürlimann B, Senn HJ: Strategies for subtypes-dealing with the diversity of breast cancer: highlights of the St Gallen international expert consensus on the primary therapy of early breast cancer 2011. Ann Oncol 2011, 22(8):1736-1747.

2. Yamashita $\mathrm{H}$ : Current research topics in endocrine therapy for breast cancer. Int J Clin Oncol 2008, 13(5):380-383.

3. Musgrove EA, Sutherland RL: Biological determinants of endocrine resistance in breast cancer. Nat Rev Cancer 2009, 9(9):631-643.

4. Shanle EK, Xu W: Selectively targeting estrogen receptors for cancer treatment. Adv Drug Deliv Rev 2010, 62(13):1265-1276.

5. CTSU RI: Effects of chemotherapy and hormonal therapy for early breast cancer on recurrence and 15-year survival: an overview of the randomised trials. Lancet 2005, 365:1687-1717.

6. Singh RR, Kumar R: Steroid hormone receptor signaling in tumorigenesis. J Cell Biochem 2005, 96(3):490-505.
7. Medunjanin S, Weinert S, Schmeisser A, Mayer D, Braun-Dullaeus RC: Interaction of the double-strand break repair kinase DNA-PK and estrogen receptor-\{alpha\}. Mol Biol Cell 2010, 21(9):1620-1628.

8. Rodriguez BA, Cheng AS, Yan PS, Potter D, Agosto-Perez FJ, Shapiro CL, Huang TH: Epigenetic repression of the estrogen-regulated Homeobox B13 gene in breast cancer. Carcinogenesis 2008, 29(7):1459-1465.

9. Iorns E, Turner NC, Elliott R, Syed N, Garrone O, Gasco M, Tutt AN, Crook T, Lord CJ, Ashworth A: Identification of CDK10 as an important determinant of resistance to endocrine therapy for breast cancer. Cancer Cell 2008, 13(2):91-104

10. Haupt $Y$, Alexander WS, Barri G, Peter Klinken S, Adams JM: Novel zinc finger gene implicated as myc collaborator by retrovirally accelerated lymphomagenesis in E [mu]-myc transgenic mice. Cell 1991, 65(5):753-763.

11. Shao Z, Raible F, Mollaaghababa R, Guyon JR, Wu C, Bender W, Kingston RE: Stabilization of chromatin structure by PRC1, a Polycomb complex. Cell 1999, 98(1):37-46.

12. Kotake $Y$, Cao $R$, Viatour $P$, Sage J, Zhang $Y$, Xiong $Y$ : pRB family proteins are required for $\mathrm{H} 3 \mathrm{~K} 27$ trimethylation and Polycomb repression complexes binding to and silencing p16 ${ }^{\text {INK4a }}$ tumor suppressor gene. Gene Dev 2007, 21(1):49-54.

13. Guo WJ, Datta S, Band V, Dimri GP: Mel-18, a polycomb group protein, regulates cell proliferation and senescence via transcriptional repression of Bmi1 and c-Myc oncoproteins. Mol Biol Cell 2007, 18(2):536-546.

14. Liu S, Dontu G, Mantle ID, Patel S, Ahn N, Jackson KW, Suri P, Wicha MS: Hedgehog signaling and Bmi1 regulate self-renewal of normal and malignant human mammary stem cells. Cancer Res 2006, 66(12):6063-6071.

15. Raaphorst FM: Self-renewal of hematopoietic and leukemic stem cells: a central role for the Polycomb-group gene Bmi1. Trends Immunol 2003, 24(10):522-524.

16. Vonlanthen S, Heighway J, Altermatt H, Gugger M, Kappeler A, Borner M, van Lohuizen M, Betticher D: The bmi1 oncoprotein is differentially expressed in non-small cell lung cancer and correlates with INK4A-ARF locus expression. Br J Cancer 2001, 84(10):1372-1376.

17. Silva J, García V, García JM, Peña C, Domínguez G, Díaz R, Lorenzo Y, Hurtado A, Sánchez A, Bonilla F: Circulating Bmi1 mRNA as a possible prognostic factor for advanced breast cancer patients. Breast Cancer Res 2007, 9(4):R55

18. Engelsen I, Mannelqvist M, Stefansson I, Carter S, Beroukhim R, Øyan A, Otte A, Kalland K, Akslen L, Salvesen H: Low Bmi1 expression is associated with an activated Bmi1-driven signature, vascular invasion, and hormone receptor loss in endometrial carcinoma. Br J Cancer 2008, 98(10):1662-1669.

19. Xu Z, Liu H, Lv X, Liu Y, Li S, Li H: Knockdown of the Bmi1 oncogene inhibits cell proliferation and induces cell apoptosis and is involved in the decrease of Akt phosphorylation in the human breast carcinoma cell line MCF-7. Oncol Rep 2011, 25(2):409-418.

20. Hoenerhoff MJ, Chu I, Barkan D, Liu ZY, Datta S, Dimri GP, Green JE: Bmi1 cooperates with H-RAS to induce an aggressive breast cancer phenotype with brain metastases. Oncogene 2009, 28(34):3022-3032.

21. Pietersen $A M$, Horlings HM, Hauptmann M, Langerod A, Ajouaou A, Cornelissen-Steijger P, Wessels LF, Jonkers J, van de Vijver MJ, van Lohuizen M: EZH2 and Bmi1 inversely correlate with prognosis and TP53 mutation in breast cancer. Breast Cancer Res 2008, 10(6):R109.

22. Guo BH, Feng Y, Zhang R, Xu LH, Li MZ, Kung HF, Song LB, Zeng MS: Bmi1 promotes invasion and metastasis, and its elevated expression is correlated with an advanced stage of breast cancer. Mol Cancer 2011, 10(1):10-33

23. Hammond ME, Hayes DF, Dowsett M, Allred DC, Hagerty KL, Badve $S$, Fitzgibbons PL, Francis G, Goldstein NS, Hayes M, Hicks DG, Lester S, Love R, Mangu PB, McShane L, Miller K, Osborne CK, Paik S, Perlmutter J, Rhodes A, Sasano H, Schwartz JN, Sweep FC, Taube S, Torlakovic EE, Valenstein P, Viale $G$, Visscher D, Wheeler T, Williams RB, et al: American society of clinical oncology/college of American Pathologists guideline recommendations for immunohistochemical testing of estrogen and progesterone receptors in breast cancer. J Clin Oncol 2010, 28(16):2784-2795.

24. Wolff AC, Hammond MEH, Schwartz JN, Hagerty KL, Allred DC, Cote RJ, Dowsett M, Fitzgibbons PL, Hanna WM, Langer A: American society of clinical oncology/college of American Pathologists guideline recommendations for human epidermal growth factor receptor 2 testing in breast cancer. Arch Pathol Lab Med 2007, 131(1):18-43.

25. Dowsett M, Nielsen TO, A'Hern R, Bartlett J, Coombes RC, Cuzick J, Ellis M, Henry NL, Hugh JC, Lively T: Assessment of Ki-67 in breast cancer: 
recommendations from the international Ki-67 in breast cancer working group. J Natl Cancer Inst 2011, 103(22):1656-1664.

26. Essafi A, Gomes AR, Pomeranz KM, Zwolinska AK, Varshochi R, McGovern UB, Lam EW: Studying the subcellular localization and DNA-binding activity of FoxO transcription factors, downstream effectors of PI3K/Akt. Methods Mol Biol 2009, 462:201-211.

27. Li SK, Smith DK, Leung WY, Cheung AM, Lam EW, Dimri GP, Yao K-M: FoxM1c counteracts oxidative stress-induced senescence and stimulates Bmi1 expression. J Biol Chem 2008, 283(24):16545-16553.

28. Yang J, Chai L, Liu F, Fink LM, Lin P, Silberstein LE, Amin HM, Ward DC, Ma $Y$ : Bmi1 is a target gene for SALL4 in hematopoietic and leukemic cells. Proc Natl Acad Sci USA 2007, 104(25):10494.

29. Cicatiello L, Addeo R, Sasso A, Altucci L, Petrizzi VB, Borgo R, Cancemi M, Caporali S, Caristi S, Scafoglio C: Estrogens and progesterone promote persistent CCND1 gene activation during G1 by inducing transcriptional derepression via c-Jun/c-Fos/estrogen receptor (progesterone receptor) complex assembly to a distal regulatory element and recruitment of cyclin D1 to its own gene promoter. Mol Cell Biol 2004, 24(16):7260-7274.

30. Sabbah M, Courilleau D, Mester J, Redeuilh G: Estrogen induction of the cyclin D1 promoter: involvement of a cAMP response-like element. Proc Natl Acad Sci USA 1999, 96(20):11217-11222.

31. Ochiai H, Takenobu H, Nakagawa A, Yamaguchi Y, Kimura M, Ohira M, Okimoto Y, Fujimura Y, Koseki H, Kohno Y, Nakagawara A, Kamijo T: Bmi1 is a MYCN target gene that regulates tumorigenesis through repression of KIF1Bbeta and TSLC1 in neuroblastoma. Oncogene 2010, 29(18):2681-2690.

32. Nowak K, Kerl K, Fehr D, Kramps C, Gessner C, Killmer K, Samans B, Berwanger B, Christiansen H, Lutz W: Bmi1 is a target gene of E2F-1 and is strongly expressed in primary neuroblastomas. Nucleic Acids Res 2006, 34(6): 1745-1754

33. Choi YJ, Choi YL, Cho EY, Shin YK, Sung KW, Hwang YK, Lee SJ, Kong G, Lee JE, Kim JS: Expression of Bmi1 protein in tumor tissues is associated with favorable prognosis in breast cancer patients. Breast Cancer Res $\mathrm{Tr}$ 2009, 113(1):83-93.

34. Bohn OL, Fuertes-Camilo M, Navarro L, Saldivar J, Sanchez-Sosa S: p16 $6^{\text {INK4a }}$ expression in basal-like breast carcinoma. Int I Clin Exp Pathol 2010, 3(6):600-607.

35. da Silveira GG, Oliveira-Costa JP, Soave DF, Zanetti JS, Soares FA, Ribeiro-Silva A: Relationship between B-Cell-specific moloney murine leukemia virus integration site 1 (Bmi1) and homologous recombination regulatory genes in invasive ductal breast carcinomas. Histol Histopathol 2012, 27(10):1353-1359.

36. O'Lone R, Frith MC, Karlsson EK, Hansen U: Genomic targets of nuclear estrogen receptors. Mol Endocrinol 2004, 18(8):1859-1875.

37. Gruber CJ, Gruber DM, Gruber IM, Wieser F, Huber JC: Anatomy of the estrogen response element. Trends Endocrinol Metab 2004, 15(2):73-78

38. Cicatiello L, Scafoglio C, Altucci L, Cancemi M, Natoli G, Facchiano A, lazzetti G, Calogero R, Biglia N, de Bortoli M, Sfiligoi C, Sismondi P, Bresciani F, Weisz A: A genomic view of estrogen actions in human breast cancer cells by expression profiling of the hormone-responsive transcriptome. $J \mathrm{Mol}$ Endocrinol 2004, 32(3):719-775.

39. Dublin EA, Patel NK, Gillett CE, Smith P, Peters G, Barnes DM: Retinoblastoma and $\mathrm{p} 16^{\text {INK4a }}$ proteins in mammary carcinoma: their relationship to cyclin D1 and histopathological parameters. Int I Cancer 1998, 79(1):71-75.

40. Arnold A, Papanikolaou A: Cyclin D1 in breast cancer pathogenesis. J Clin Oncol 2005, 23(18):4215-4224.

41. Cánepa ET, Scassa ME, Ceruti JM, Marazita MC, Carcagno AL, Sirkin PF, Ogara MF: INK4 proteins, a family of mammalian CDK inhibitors with novel biological functions. IUBMB Life 2007, 59(7):419-426.

42. O'Neill CJ, McCluggage WG: $16^{\text {INK4a }}$ expression in the female genital tract and its value in diagnosis. Adv Anat Pathol 2006, 13(1):8-15.

43. Kalof AN, Cooper K: p $16^{1 \mathrm{NK} 4 \mathrm{a}}$ immunoexpression: surrogate marker of high-risk HPV and high-grade cervical intraepithelial neoplasia. Adv Anat Pathol 2006, 13(4):190-194.
44. Meng S, Luo M, Sun H, Yu X, Shen M, Zhang Q, Zhou R, Ju X, Tao W, Liu D: Identification and characterization of Bmi1-responding element within the human p16 ${ }^{\text {INK4a }}$ promoter. J Biol Chem 2010, 285(43):33219-33229.

45. Pietersen AM, Evers B, Prasad AA, Tanger E, Cornelissen-Steijger P, Jonkers J, van Lohuizen $\mathrm{M}$ : Bmi1 regulates stem cells and proliferation and differentiation of committed cells in mammary epithelium. Curr Bio/ 2008 , 18(14):1094-1099.

doi:10.1186/1471-2407-14-122

Cite this article as: Wang et al:: Estrogen receptor a-coupled Bmi1 regulation pathway in breast cancer and its clinical implications. BMC Cancer 2014 14:122.

\section{Submit your next manuscript to BioMed Central and take full advantage of:}

- Convenient online submission

- Thorough peer review

- No space constraints or color figure charges

- Immediate publication on acceptance

- Inclusion in PubMed, CAS, Scopus and Google Scholar

- Research which is freely available for redistribution

Submit your manuscript at www.biomedcentral.com/submit
C Biomed Central 